Journal of Southeast Asian

\title{
[Special Issue on SEA Demographics] Response - Asian American Studies
}

Peter Nien-Chu Kiang

University of Massachusetts, Boston, peter.kiang@umb.edu

Follow this and additional works at: https://docs.lib.purdue.edu/jsaaea

Part of the Asian American Studies Commons

\section{Recommended Citation}

Nien-Chu Kiang, Peter (2008) "[Special Issue on SEA Demographics] Response - Asian American Studies," Journal of Southeast Asian American Education and Advancement. Vol. 3 : Iss. 1, Article 9. DOI: $10.7771 / 2153-8999.1105$

Available at: https://docs.lib.purdue.edu/jsaaea/vol3/iss1/9

This document has been made available through Purdue e-Pubs, a service of the Purdue University Libraries. Please contact epubs@purdue.edu for additional information.

This is an Open Access journal. This means that it uses a funding model that does not charge readers or their institutions for access. Readers may freely read, download, copy, distribute, print, search, or link to the full texts of articles. This journal is covered under the CC BY-NC-ND license. 


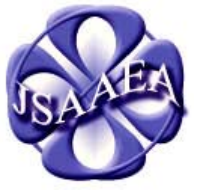

Volume 3

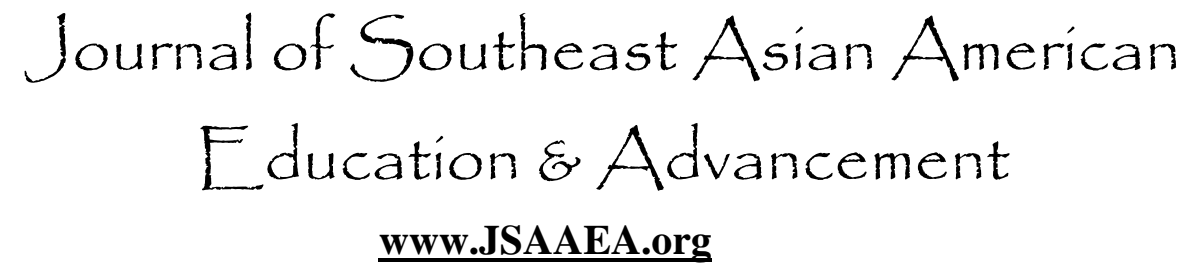

WWW.JSAAEA.org
A peer-reviewed

scholarly journal

published by the

National Association

for the Education \&

Advancement of

Cambodian, Laotian, and Vietnamese Americans (NAFEA)

\title{
Special Issue on Southeast Asian American Demographics
}

\section{Response-Asian American Studies}

\author{
Peter Nien-chu Kiang \\ University of Massachusetts Boston
}

\section{Introduction}

Following a poorly attended panel on Southeast Asian American community research at the 1996 national conference of the Association for Asian American Studies (AAAS) in Oakland, Chung Hoang Chuong commented to me, "I think it's time for Vietnamese American Studies to stand on its own." As the most active Vietnamese American scholar in the Asian American Studies field at that time, Anh Chuong was unsatisfied and impatient with the lumping of Vietnamese American content under not only the pan-Asian umbrella, but also the imposed category of "Southeast Asian." His comment has stayed with me since then, informing and challenging my own commitments as a researcher/teacher/advocate in relation to Southeast Asian American students and communities.

Much of my own agenda working in the intersections between the fields of education and Asian American Studies, therefore, has focused on documenting and analyzing the voices, strengths, and needs of Vietnamese, Cambodian, and other Southeast Asian immigrant/refugee students, precisely because of the failure of educational institutions to support or even acknowledge them. Inspired by those same students, I have also explored how specific curricular and pedagogical commitments in Asian American Studies can serve as models of transformative practice for higher education in the United States (Kiang \& Tang, 2006; Kiang, 2004, 2003, 2002, 2000, 1997).

\section{Reflections on Data}

Researchers and practitioners involved with Asian American communities during the past three decades have consistently focused on the need for disaggregated population data as one leg of our ongoing critique of the pervasive stereotypic assumption by policy-makers and the public that Asian Americans are doing well in U.S. society. Going beyond critique, Mark Pfeifer and the Journal of Southeast Asian American Education and Advancement (JSAAEA) offer a helpful summary of recent U.S. Census data specifically for Cambodian, Hmong, Lao, and Vietnamese (CHLV) populations in the United States. Pfeifer's disaggregated compilation helps us to recognize current realities and continuing dynamics such as geographic spread, generational

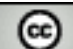

SORERIGHISRESERVEDReaders are free to copy, display, and distribute this article, as long as the work is attributed to the author(s) and the Journal of Southeast Asian American Education \& Advancement, it is distributed for noncommercial purposes only, and no alteration or transformation is made in the work. More details of this Creative Commons license are available at http://creativecommons.org/licenses/by-nc-nd/3.0/. All other uses must be approved by the author(s) or JSAAEA. 
change, and persistent poverty amidst educational and socioeconomic progress. I hope others will comment more fully on these aspects of Pfeifer's article. Building on Pfeifer's gentle analysis regarding similarities, differences, and diversity between and within each population, I highlight specific observations about disability status and language use. I also offer additional reflections about gathering meaningful data, developing relevant sites of research, and teaching from the vantage point of the Asian American Studies field.

Given limited space, I specifically focus on Pfeifer's inclusion of disability status as a category of analysis, and suggest that this is an especially important set of issues and needs to be addressed. Given the disabling, long-term, physical and psychological health consequences resulting from war, genocide, malnutrition, hard labor, and forced migration, the disproportionately high incidence of disabilities reported specifically for elders of each population is undeniable and should be a focal point for collective intervention and advocacy. Here, the role of community health centers with bilingual health professionals and outreach workers is critical. At the same time, indigenous community sites of support and healing for elders-particularly temples and churches-also need to be recognized and supported (funded) as culturally-responsive centers for disability services. Furthermore, we know from clinical research with U.S. Vietnam veterans and their children that numerous second-generation effects have been passed on from survivors of war, including effects such as Post traumatic Stress Disorder (PTSD) and exposure to toxic chemicals. In addition, while race-based claims for equity/justice have been dramatically undermined by government policies and judicial rulings during the past three decades, disability rights are still relevant among categories of protected classes recognized by the bureaucracies of municipal, state, and federal government that are mandated to respond to claims of discrimination while ensuring fair delivery of public services. Our responsive capacities are severely limited due both to the small number of trained bilingual/bicultural practitioners among each population and the effect of sociocultural stigma associated with disabilities. Nevertheless, the intersection of disability issues with CHLV profiles locally and nationally, particularly for elders, deserves far greater attention from all sectors.

Pfeifer also includes a specific section on language, noting the very high proportions within each population-roughly nine out of ten-that report use of a language other than English at home. Given the sociocultural significance of native language use and heritage language maintenance across generations within refugee/immigrant families and communities, our analysis needs to recognize the indigenous power and influence of Hmong, Khmer, Lao, and Vietnamese linguistic capacities, rather than as barriers in relation to the dominance of English in U.S. society. To address the critical needs of monolingual elders with disabilities as noted above, for example, the role of bilingual health practitioners is crucial to expand. However, the role of other indigenous facilitators of health, wellness, and learning such as monks who are typically monolingual themselves, also needs to be supported and enhanced. Indeed, temples and churches are significant sites for researchers to recognize, not only in relation to health issues, but also as sites of youth development and heritage language education, together with other models of community-based heritage language teaching/learning that take place after school and on weekends as an alternative to the lack of opportunities available within public school districts. The maintenance and reinvigoration of heritage languages for these populations also is related to family and community access to diasporic communication and interaction through internet technology and homeland travel, both of which are surveyed regularly. 


\section{Reflections on Relevant Research and the Meanings of Progress}

An excellent example of applied research that models multilingual capacity while documenting native language significance is the annual Asian American community exit polling conducted by the Asian American Legal Defense \& Education Fund (AALDEF). In November 2004, for example, AALDEF conducted a national, multilingual exit poll of nearly 11,000 Asian American voters $(n=10,789)$ across eight states and 23 cities in the United States. AALDEF's path breaking research in 2004, and again in 2005, included a Vietnamese community site in Boston's Fields Corner/Dorchester neighborhood and a Cambodian community site in Lowell, Massachusetts (in addition to also Falls Church, VA and Providence, RI) (Asian American Legal Defense and Education Fund, 2006, 2005). Though Southeast Asians comprised only six percent of AALDEF's total national sample in 2004, they represented nearly half (47\%) of all respondents in Massachusetts (MA total $n=777$ ) (Kiang \& Tang, 2006).

In addition to revealing the basic role of language in Asian voter participation, a distinct, but related contribution of AALDEF's study is to show the influence of ethnic media as critical sources of news about politics and community issues (Kiang \& Tang, 2006). For Southeast Asian's in Massachusetts, for example, 62\% of Vietnamese respondents relied on ethnic media sources compared to just 38\% who utilized mainstream English language media. Similarly, 56\% of Cambodian respondents in Massachusetts got their news about politics and community issues from ethnic media sources compared to 44\% who used mainstream media sources (Asian American Legal Defense and Education Fund, 2005). Clearly, ethnic media outlets—ranging from native language and bilingual newspapers to radio and cable television programming and internet sites-provide crucial sources of information and ideas about politics and community affairs for many Southeast Asian Americans. It is also reasonable to assume that ethnic community-based media sources are even more widely utilized by Southeast Asian (and other Asian) constituencies not included in AALDEF's sample-those who are not U. S. voters due to limited English proficiency, length of U.S.-residency, immigration/naturalization status, or other reasons.

AALDEF's exit poll studies are consistent with Pfeifer's call for additional quantitative and qualitative research beyond Census data collection. Such research generates useful local and national data annually through multilingual methods across multiple locations. Furthermore, it helps to clarify one of Pfeifer's basic conclusions that "members of the four Southeast Asian American groups are making substantial socioeconomic and educational progress with time in the United States” (p. 17). Engagement with local, state, and national electoral politics in the United States understandably should be considered one of the indicators that offer deeper insight about how "progress" is demonstrated.

Other examples of relevant data to collect or compile that would be helpful descriptively and analytically might include religious affiliation and generational cohort. For example, a third generation of Vietnamese Americans - the children of the U.S.-born children of first-wave professionals who escaped Vietnam in 1975-are already entering elementary school. Their realities as "sansei" (to use the foundational sociolinguistics of Asian American Studies) require dramatic redefinitions of Vietnamese American communities as "refugees" and "newcomers." The upcoming 2010 Census can be expected to show an age/migration distribution with many from the refugee waves of the 1980s as elders with U.S.-born children and third generation grandchildren. 
Redefinitions are also necessary regarding meanings and trajectories of "acculturation" which are not only non-linear, due to CHLV populations' continuing, if not expanding, diasporic, transnational commitments, but that are also significantly shaped by the influences of predominantly Black/Latino locations rather than predominantly white contexts which are typically, albeit uncritically, assumed to be the focal point for defining minority and immigrant "progress" in U.S. society. Historic dynamics of refugee resettlement intersecting with geographies of poverty and low-income housing have resulted in significant clusters of these populations being concentrated in urban areas where, particularly for younger generations, the "progress" of adaptation has been intensely defined by hip-hop cultural reference points and dimensions of racial "disparities" in public health, racial "achievement gaps" in public education, and racial "profiling” vis-à-vis the criminal justice system. Closer analysis of the Census data summarized by Pfeifer might reveal, for example, the proximity of specific CHLV populations to larger patterns of urban residential segregation and possible associations with what Gary Orfield and his Civil Rights project colleagues have documented as school re-segregation (Orfield \& Lee, 2006).

Closer analysis of the "alone or in any combination" population profiles used by Pfeifer might also reveal dimensions of "progress" within these multiracial contexts as represented by the diversity among mixed-race CHLV populations, including not only the large number of foreign-born “Amerasians," but also significant numbers who are mixed-race Black and mixedrace non-white Hispanic. At the same time, these complex understandings of multiracial urban social contexts are further complicated by the intentional spread of specific populations, particularly for the Hmong, away from cities to more rural settings, as Pfeifer also clearly notes.

Finally, while underlining their progress, Pfeifer also concludes that each group has "come to the United States from very different circumstances and past experiences in Southeast Asia and is advancing at a different trajectory" (p. 17). These complex, intersecting, and distinct data profiles are important to address not only through relevant research, but also in the critical domain of the curriculum.

\section{Reflections on the "Progress" of Southeast Asian American Studies Praxis}

Southeast Asian American Studies researchers and topics regrettably remain relatively marginal within the larger field of Asian American Studies (Kiang, 2003). The establishment of JSAAEA and the ongoing work of Mark Pfeifer represent significant interventions. In this same spirit, my own university's Asian American Studies Program has also made a modest but sustained commitment to Southeast Asian American Studies research and documentation as well as teaching and learning. The immediate neighborhood next to the University of Massachusetts, Boston is home to the fifth largest Vietnamese community in the United States. Khmer communities in Lowell and Lynn/Revere - the second and fifth largest in the country-are nearby as well.

Although the majority of more than 20 courses offered by our Asian American Studies Program includes some readings, case studies, or projects about Southeast Asian American issues, we have specifically offered "Southeast Asians in the U.S." each semester since 1989. This course examines the processes of migration, refugee resettlement, and community development for Vietnamese, Lao, and Cambodians nationally and locally, and the interplay of themes of trauma, healing, and resilience with changing contexts of families, communities, schools, public policies, and homeland relations. 
As one of the first courses in the United States developed with this focus in the 1980s, "Southeast Asians in the U.S." has been offered about 40 times since 1989, reaching about 1200 students of whom roughly half have been Vietnamese, Cambodian, and ethnic Chinese from Southeast Asia, along with smaller numbers of Lao and Hmong. In the early 1990s, most students were second-wave refugees with direct memories of war and refugee flight; in the 2000s, many students are U.S. born, some were babies during the second-wave migrations, and others came as teens from Vietnam with their fathers and families during the mid-1990s through the Humanitarian Operation program. Sustained classroom-based research with Southeast Asian American students has added much-needed, grounded perspectives to the body of literature about culturally responsive curriculum and pedagogy in the fields of education and Asian American Studies.

Furthermore, Lao, Khmer, and Vietnamese American graduate students and advanced undergraduates, have regularly served as teaching assistants in "Southeast Asians in the U.S." who are now community advocates and bilingual educators themselves. The course has also provided important teaching opportunities for Southeast Asian American community practitioners and graduate students, including a former coordinator of the Massachusetts Office for Refugee Resettlement (Chinese Cambodian), a former undergraduate who became the first Vietnamese American to receive a doctorate in education from Harvard, and a former program staff who is the first Lao American enrolled in Harvard's education doctoral program. With so few Southeast Asian American faculty members in U.S. universities, courses like "Southeast Asians in the U.S." serve not only as interventions for students and communities, but also as critical opportunities for individual faculty mentoring and development.

Recalling Chung Hoang Chuong's assertion that Vietnamese American Studies should stand on its own, however, we developed a new course, "Resources for Vietnamese American Studies," in 2002-2003 to explore ways of studying the reconstructions of identity, culture, and community for Vietnamese in the United States and their diasporic relationships around the world. Taught bilingually by a community practitioner, the course featured presentations by local Vietnamese American researchers, writers, and community leaders and visiting scholars. In 2007, the course was embedded with distance-learning and service-learning capacities to support Vietnamese community rebuilding in the post-Katrina Gulf Coast settings of New Orleans East, Louisiana and East Biloxi, Mississippi with 22 students contributing directly to research, organizing, and planning in support of projects related to environmental justice, business and real estate development, community gardening, and advocacy.

A parallel course titled "Cambodian American Culture and Communities" was also offered for the first time in 2003 and every third semester since then as part of a larger strategy to support pathways that enable more Cambodian American students to pursue undergraduate and graduate programs at the university. Interestingly, the Cambodian American Studies course, in particular, along with the other two courses described above, have reached not only CHLV student populations from those ethnic and racial groups, but also students with refugee backgrounds from Sudan, the Republic of the Congo, Haiti, Lebanon, and Iran. For example, one student majoring in Africana Studies who had come with his family to the United States from Somalia just a few years earlier, took "Cambodian American Culture and Community" to deepen his personal, comparative, and applied understandings of refugee realities. He was inspired to begin to design and develop, with support from the Asian American Studies Program, a future course dedicated to Somali American Studies. 
Though these curricular commitments have evolved demographically-grounded in the dynamic, distinct, diverse realities of the populations described by Pfeifer-they also reflect meanings of "progress" that we have intentionally crafted. The crafting of JSAAEA's commitments to content, process, and praxis over time should be just as intentional, with this issue's invitation to Mark Pfeifer serving as one such example.

\section{References}

Asian American Legal Defense and Education Fund. (2006). The Asian American vote: A report on the multilingual exit poll in the 2005 Massachusetts Election. Author: New York.

Asian American Legal Defense and Education Fund. (2005). The Asian American vote: A report on the multilingual exit poll in the 2004 Presidential Election. Author: New York.

Kiang, P. N. (2004). Checking Southeast Asian American realities in Pan-Asian American agendas. AAPI Nexus: Policy, Practice \& Community, 2(1), 48-76.

Kiang, P. N. (2003). Pedagogies of PTSD: Circles of healing with refugees and veterans in Asian American studies. In L. Zhan (Ed.), Asian Americans: Vulnerable populations, model interventions, clarifying agendas (pp. 197-222). Sudbury, MA: Jones \& Bartlett.

Kiang, P. N. (2002). Stories and structures of persistence: Ethnographic learning through research and practice in Asian American studies. In Y. Zou \& H. T. Trueba (Eds.), Ethnography and schools: Qualitative approaches to the study of education, (pp. 223255) Lanham, MD: Rowman \& Littlefield.

Kiang, P. N. (2000). Wanting to go on: Healing and transformation at an Urban Public University. In E. T. Trueba \& L. I. Bartolomé (Eds.), Immigrant voices: In search of educational equity (pp. 137-166). Lanham, MD: Rowman \& Littlefield.

Kiang, P. N. (1997). Pedagogies of life and death: Transforming immigrant/refugee students and Asian American studies. Positions, 5(2), 529-555.

Kiang, P. N. \& Tang, S. S-L. (2006). Electoral politics and the contexts of empowerment, displacement, and diaspora for Boston's Vietnamese and Cambodian American communities. Asian American Policy Review, 15, 13-29.

Orfield, G. \& Lee. C. (2007). Historic reversals, accelerating resegregation, and the need for new integration strategies (Civil Rights Project/Proyecto Derechos Civiles report). Los Angeles: University of California, Los Angeles. Retrieved June 5, 2008 from www.civilrightsproject.ucla.edu/research/deseg/reversals_reseg_need.pdf 


\section{About the Author}

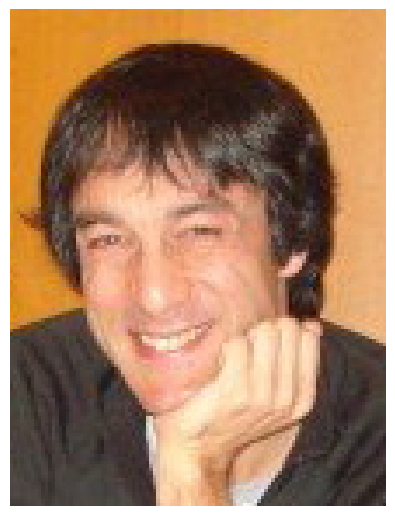

Dr. Peter Nien-chu Kiang (江念祖) is Professor of Education and Director of the Asian American Studies Program at the University of Massachusetts Boston where he has taught since 1987. Peter's research, teaching, and advocacy in both K-12 and higher education with Asian American immigrant/refugee students and communities have been supported by the National Academy of Education, the National Endowment for the Humanities, the Massachusetts Teachers Association, the Massachusetts Association for Bilingual Education, and others. In 2007, he received the Chancellor's Distinguished Teaching Award at UMass Boston. He is currently co-president of the Chinese Historical Society of New England and chair of the Massachusetts Advisory Committee for the U.S. Commission on Civil Rights. He holds a B.A., Ed.M., and Ed.D. from Harvard University and is a former Community Fellow in the Department of Urban Studies and Planning at MIT. 


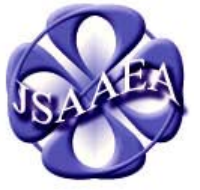

Volume 3

\section{Journal of Southeast Asian American Education \& Advancement} WWW.JSAAEA.org

\section{Editor}

Dr. Wayne E. Wright

University of Texas, San Antonio

Associate Editors

Dr. Chhany Sak-Humphry

University of Hawaii

Dr. KimOanh Nguyen-Lam

California State University, Long Beach

Book Review Editor

Dr. Leslie Turpin

School for International Training

Creative Works Editor

Phouang Hamilton

Washington Office of Superintendent of Public Instruction

Special Advisor

Anne Frank

University of California, Irvine, Southeast Asian Archives

\author{
Editorial Assistant \\ Mariana Kuhl \\ University of Texas, San Antonio
}

A peer-reviewed scholarly journal published by the National Association for the Education \& Advancement of Cambodian, Laotian, and Vietnamese Americans (NAFEA)

Comments and questions for the editorial staff may be directed to jsaaea@lists.sis.utsa.edu

\section{Editorial Review Board}

\author{
Dr. Carl L. Bankston III \\ Tulane University \\ Dr. Phala Chea \\ Lowell Public Schools \\ Dr. Changming Duan \\ University of Missouri, Kansas City \\ Dr. Nancy H. Hornberger \\ University of Pennsylvania \\ Dr. Peter Nien-Chu Kiang \\ University of Massachusetts, Boston
}

\author{
Dr. Pollie Bith-Melander \\ Asian and Pacific Islander Wellness center \\ Dr. George Chigas \\ University of Massachusetts, Lowell \\ Dr. Sophal Ear \\ U.S. Naval Postgraduate School \\ Dr. Samlong Inthaly \\ Minneapolis Public Schools \\ Dr. Kevin K. Kumashiro \\ University of Illinois, Chicago
}


Nien-Chu Kiang: [Special Issue on SEA Demographics] Response - Asian American Stu

\author{
Dr. Stacey Lee \\ University of Wisconsin, Madison \\ Dr. Sue Needham \\ California State University, Dominguez Hills \\ Dr. Max Niedzwiecki \\ Rights Working Group \\ Dr. Clara Park \\ California State University, Northridge \\ Dr. Loan T. Phan \\ University of New Hampshire \\ Dr. Karen Quintiliani \\ California State University, Long Beach \\ Dr. Fay Shin \\ California State University, Long Beach \\ Dr. Yer J. Thao \\ Portland State University \\ Dr. Khatharya Um \\ University of California, Berkeley \\ Dr. Terrence G. Wiley \\ Arizona State University
}

Dr. David Chanpannha Ley

Montgomery County Public Schools

Dr. Bic Ngo

University of Wisconsin-Madison

Dr. Leakhena Nou
California State University, Long Beach
Dr. Mark Pfeifer
Texas A\&M University, Corpus Christi

Dr. Bounlieng Phommasouvanh

Minnesota Department of Education

Dr. Kalyani Rai

University of Wisconsin, Milwaukee

Dr. Nancy J. Smith-Hefner

Boston University

Dr. Myluong Tran

San Diego State University

Dr. Linda Trinh Vo

University of California, Irvine

Dr. Zha Blong Xiong

University of Minnesota

Dr. Kou Yang

California State University, Stanislaus

\section{Doctoral Student Editorial Review Board}

\section{Keo Chea}

University of Pennsylvania

Loan Dao

University of California, Berkeley

Ha Lam

Arizona State University

Vanna Som

Harvard University

Giang Pham

University of Minnesota

Tinou Tran

University of Houston, Texas

Phitsamay Sychitkokhong Uy

Harvard University
Vichet Chhuon

University of California, Santa Barbara

Annie BichLoan Duong

San Joaquin County Office of Education

Ravy Lao

University of California, Santa Barbara

Rassamichanh Souryasack

University of California, Santa Barbara

Layheng Ting

State University of New York, Albany

\section{Loan Tran}

University of California, Santa Barbara

Yang Sao Xiong

University of California, Los Angeles 